\title{
A Numerical Study of the Beijing Extreme Rainfall of 21 July 2012 and the Impact of Topography
}

\author{
Hongxiong $\mathrm{Xu}$ and Wenqing Yao \\ State Key Laboratory of Severe Weather, Chinese Academy of Meteorological Sciences, Beijing 100081, China \\ Correspondence should be addressed to Wenqing Yao; yaowq@cams.cma.gov.cn
}

Received 22 January 2015; Revised 4 May 2015; Accepted 4 May 2015

Academic Editor: S. Vicente-Serrano

Copyright ( $) 2015$ H. Xu and W. Yao. This is an open access article distributed under the Creative Commons Attribution License, which permits unrestricted use, distribution, and reproduction in any medium, provided the original work is properly cited.

\begin{abstract}
The extreme rainfall on 21 July 2012 is the heaviest rainfall that has occurred in Beijing since 1961. Observations and WRF (Weather Research and Forecasting) model are used to study the effect of MCS (mesoscale convective system) and topography on the rainfall. In this high-impact event, a quasi-stationary MCS developed in a favorable moist environment. The numerical simulation successfully reproduced the amount, location, and time evolution of the rainfall despite 4-6h delay. In particular, the model reproduced the repeat passage of convective cells at the leading convergence line region along Taihang Mountains and the trailing stratiform region, producing the rainfall at nearly the right position. Results indicate the important roles of mesolow and low-level jet in maintaining the conditional instability that lifted the moist air to trigger deep convection and the repeated initiation and movement of the line shaped convective cells that produced the rainfall. The sensitive experiment was then further carried out to examine the effect of topography on this heavy rainfall. The reduction in model elevation field significantly influenced the above mesoscale systems, which lead to convective cells becoming less organized, and the peak rainfall amount in Beijing decreased by roughly $50 \%$.
\end{abstract}

\section{Introduction}

Extreme rainfall is responsible for a variety of societal impacts, including flash flooding that can lead to damage, injury, and death [1]. Thus, it is of great interest to accurately predict extreme rainfall. However, heavy rainfall associates with multiscale nonlinear interactions [2]. Although the ability of NWP (numerical weather prediction) has been improved rapidly, the accurate prediction of warm-season precipitation remains a tough task $[3,4]$. A large portion of the extreme rainfall events are produced by MCS, and the amount of rainfall is often associated with characteristics of MCSs (Schumacher and Johnson [5]).

The heaviest rainfall occurs where the rainfall rate is the highest for the longest time [6]. Houze et al. [7] found that flash flooding is more likely produced by linear MCSs than nonlinear ones in Oklahoma. If multiple convective cells repeatedly pass over the same area in rapid succession, extreme rainfall totals can occur [6]. This MCS organization that was commonly responsible for extreme rainfall was termed "back-building/quasi-stationary convection" (BB) by
Schumacher and Johnson [5]. Parker and Johnson [8,9] identified and described the governing dynamics of three modes of linear MCSs that are common in the central plains-those with trailing stratiform (TS) precipitation, those with leading stratiform (LS), and those with parallel stratiform.

Topography plays an important role in the development of deep convection and precipitation enhancement [10-12]. Lin et al. [13] have identified four common factors contributing to the occurrence of heavy orographic rainfalls: (1) a conditionally or potentially unstable airstream impinging on the mountains, (2) a very moist low-level jet, (3) a steep mountain, and (4) a quasi-stationary synoptic system to decelerate the convective system over the threatened area [14]. In cases where convective initiation is related to local topography (e.g., forced orographic lifting), a steady low-level wind may also ensure that new cells repeatedly form in the same location $[6,15]$.

Beijing has a complex terrain between plain and mountain. The impact of Yanshan and Taihang Mountain surrounding Beijing is an interesting research topic. The average annual rainfall in Beijing is about $420 \sim 660 \mathrm{~mm}$, which is one 
of the greatest rainfall amount region in Northern China's flat areas [16]. Beijing is a region suffering from high frequency of heavy rainfall. During 1951-2012, it was struck by 22 rainfall events (>100 mm), with two of them greater than $200 \mathrm{~mm}$ and with the highest peak up to $318.1 \mathrm{~mm}$ [17]. The formation reason of part of them was due to the important roles of topography played in the exception rainfall.

The extreme rainfall on 21 July 2012 is the heaviest rainfall in Beijing since 1961. It brought severe disasters over the region and caused 75 people to perish and \$2 billion economic losses. Zhang et al. [18] found that this extreme rainfall event appeared to be reasonably well predicted by current operational models, albeit with much smaller intensity, notable timing, and location errors. However, the modelpredicted rainfall results mainly from topographical lifting and the passage of a cold front, whereas the observed rainfall was mostly generated by convective cells. In particular, their results also indicated that high resolution convection permitting models was required in order to predict the timing, distribution, and intensity of such an extreme event more accurately.

In this study, observations are used to study the multiscale processes that produced the heavy rainfall. A convection resolving simulation is conducted to survey the skill of the WRF model in reproducing the record rainfall event in the north of China. Particularly, the numerical simulation results are then used to investigate the mesoscale and stormscale processes in triggering deep convection. Furthermore, experiments are carried out to investigate how long-lived, quasi-stationary, linearly organized convection is maintained associated complex terrain surrounding Beijing. Section 2 describes the precipitation distribution and observational analysis. Section 3 shows the configuration and experiment design of model. Section 4 verifies the simulated mesoscale processes. The results of simulations and the detailed effects of topography on formation of the extreme rainfall were presented in Section 5. Section 6 gives conclusions.

\section{Overview}

The extreme rainfall, which occurred during 21 July 2012 with a record amount of $460 \mathrm{~mm}$ (at south of Beijing), is the heaviest rainfall event ever hitting Beijing since 1961. The observed $24 \mathrm{~h}$ rainfall is shown in Figure 1. The heavy rainfall areas are mainly located in Beijing and its surrounding areas. It is estimated that the average rainfall amount received in Beijing region was over $170 \mathrm{~mm}$ during this storm event. Two apparent rainfall centers are located at south and northeast of Beijing, respectively.

Figure 2 shows the 850,500 , and $200 \mathrm{hPa}$ large-scale environments from the NCEP FNL reanalysis data at 06 UTC 21 July 2012, $6 \mathrm{~h}$ before the rainfall reached its peak intensity. Large-scale circulation showed a southwesterly monsoonal flow with high moisture over the east of China (Figures 2(a) and 2(b)). Typhoon Vicente located at South China Sea can receive moisture from southwesterly monsoonal flow and then transport part of the moisture to Beijing region along southeast flow east of subtropical high (SH) (Figure 2(a)) [19].
"Such an effect of a TC (tropical cyclone) on precipitation is generally referred to as the remote effect of a TC on precipitation" [20]. Furthermore, the upper-level trough blocked by $\mathrm{SH}$ also significantly influenced the rainfall event. Although the above large-scale synoptic systems could provide favorable conditions for rainfall, it was still not enough to lead to such an extreme rainfall in Beijing, 2012 [21]. Thus, factors like MCS and local topography may also play important roles in this event. High resolution remotely sensing observations and model are used to further investigate the other factors causing the extreme rainfall event.

\section{Model Description and Experiment Design}

The WRF model of version 3.4.1 [22] is utilized here at convection-permitting resolutions to simulate the extreme rainfall event. The model is integrated for $48 \mathrm{~h}$, starting from 0000 UTC 20 July 2012. Figure 3 shows the domain for two experiments. The model horizontal spacing is $30 \mathrm{~km}, 10 \mathrm{~km}$, and $3.3 \mathrm{~km}$ for $\mathrm{d} 01, \mathrm{~d} 02$, and $\mathrm{d} 03$. The sizes of model grids are $375 \times 246,238 \times 160$ and $394 \times 286$, respectively. All domains were 28 levels extended to $100 \mathrm{hPa}$.

The initialized condition and lateral boundary conditions of all experiments were from NCEP Global Data Assimilation System (GDAS) Final Operational Global Analyses $\left(1^{\circ} \times 1^{\circ}\right)$. The model physical options include the WSM5 microphysics scheme [23], the YSU planetary boundary layer scheme [24], the Kain-Fritsch cumulus parameterization scheme $[25,26]$, the Noah land surface model [27, 28], the Rapid Radiative Transfer Model [29] longwave, and the Dudhia shortwave radiation scheme [30]. The cumulus parameterization scheme is not applied to the finest $(3.3-\mathrm{km})$ grid domain to explicitly resolve the convective rainfall.

In addition to the experiment (CTRL) with real topography (Figure 4(a)), a sensitivity experiment (TOP0.25) is conducted to investigate the effects of mesoscale topography on the extreme rainfall. The TOP0.25 is the same as CTRL, only with the terrain in D03 which was reduced by $75 \%$ (Figure 4(b)).

\section{Model Verification}

The $24 \mathrm{~h}$ rainfall from 0000 UTC 21 to 0000 UTC 22 July 2012 of the CTRL experiment is shown in Figure 1(b). Compared with results from observations (Figure 1(a)), the finest resolution simulation in CTRL experiment captures many of the features of the observed system. It reasonably reproduces a region of significant rainfall with two maximum centers over Beijing, distribution of which is in good agreement with the observation. The model maximum rainfall amount is about $330 \mathrm{~mm}$, which is about $100 \mathrm{~mm}$ less than that observed. However, considering the large amount of rain that fell in this event and the challenges of predicting ground-accumulated rainfall when using microphysical parameterizations, this can probably be considered a reasonable result [1]. The temporal evolutions of rainfall amount at Fangshan station of both CTRL and observation are shown in Figure 5. It is notable that the rainfall of CTRL experiment displays 


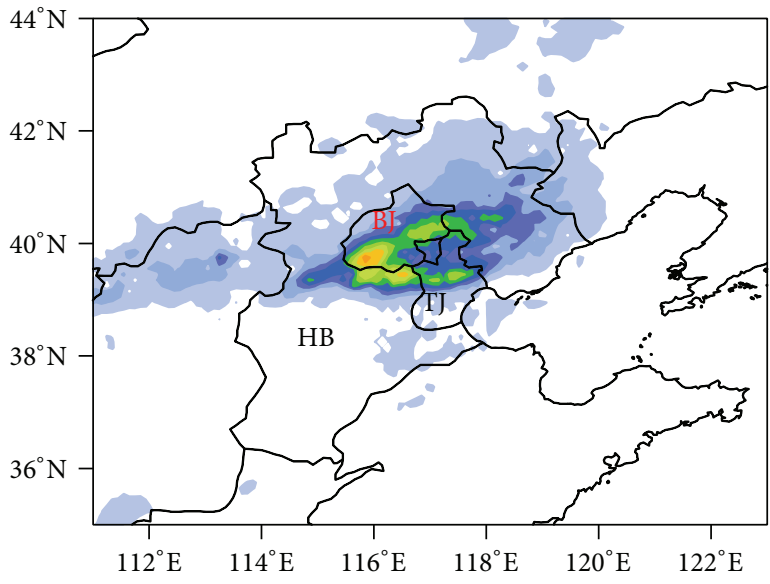

(a) OBS

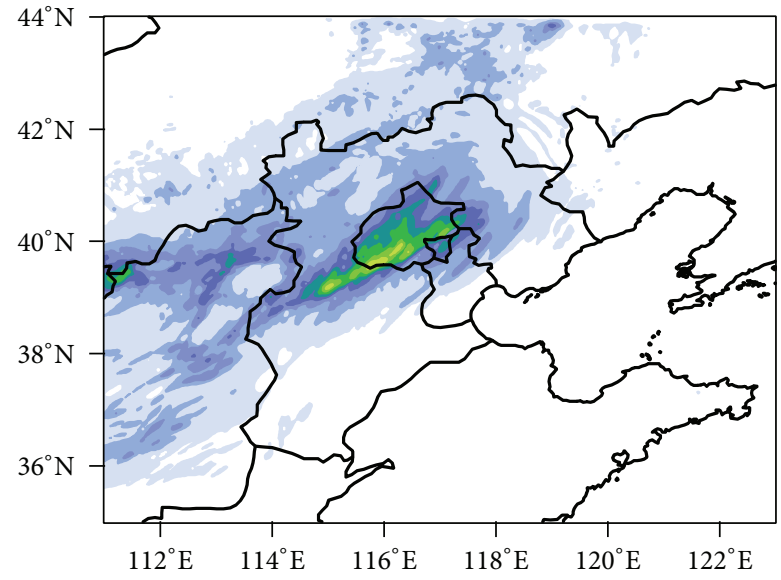

(b) CTRL

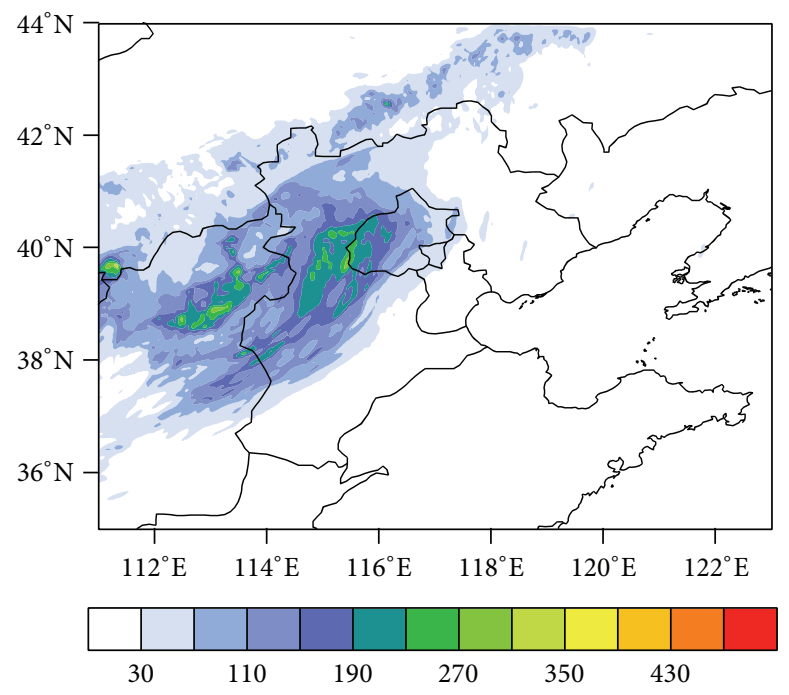

(c) TOP0.25

FIGURE 1: The $24 \mathrm{~h}$ accumulated rainfall (unit: $\mathrm{mm}$ ) from (a) observation, (b) CTRL, and (c) TOP0.25 experiment ending at 0000 UTC 22 July 2012; "BJ" (red), “TJ", and "HB” indicated Beijing and Tianjin metropolitan city and Hebei province, respectively.

two major peaks $(20 \mathrm{~mm} / \mathrm{h}$ and $58.5 \mathrm{~mm} / \mathrm{h})$ with nearly the same intensity $(21 \mathrm{~mm} / \mathrm{h}$ and $63 \mathrm{~mm} / \mathrm{h})$ as that of the observations, despite a $4-6 \mathrm{~h}$ delay. The delay which was also suggested by Hong and Lee [31] could be attributed to typical problems with the model spinup of gridbox saturation from the large-scale initial conditions [2]. Despite the timing delay, the model's ability of reproducing heavy rainfall event is encouraging, with reasonable evolution of rainfall and the heaviest precipitation in south of Beijing just as where it actually occurred.

Comparison of the observed radar reflectivity from Beijing station to the model simulated one is showed in Figure 6. Around 0600 UTC 21 July, radar observations reveal two deep convections from south of stratiform rain region (Figure 6(a)). These convections move to northeastward and grow into a quasi-linear MCS over 5-6 hours, with the system moving slowly eastward. The linear MCS shows a region of high reflectivity that is approximately $200 \mathrm{~km}$ in length and $30 \mathrm{~km}$ in width with an area of stratiform rainfall to the northeast by 1200 UTC (Figure 6(c)). The corresponding model simulated radar reflectivity is shown in Figures 6(b) and $6(\mathrm{~d})$. The two convective regions of the MCS are well reproduced in the CTRL experiment (Figure 6(b)), despite timing error and underprediction of the stratiform rain. Similar to observations, the MCS develops into a quasi-linear MCS about $6 \mathrm{~h}$ later (Figure 6(d)).

Current operational models predict the extreme rainfall with wrong reasons, which results mainly from topographical lifting and the passage of a cold front, whereas the observed rainfall is mostly generated by convective cells [18]. However, the CTRL experiment with $3 \mathrm{~km}$ resolution successfully produces a quasi-linear MCS, which shows many features of the observations. The simulation also reasonably reproduces a region of torrential rainfall amount over Beijing with the location and the distribution in good agreement with the observations. Thus, it can be concluded that the results 


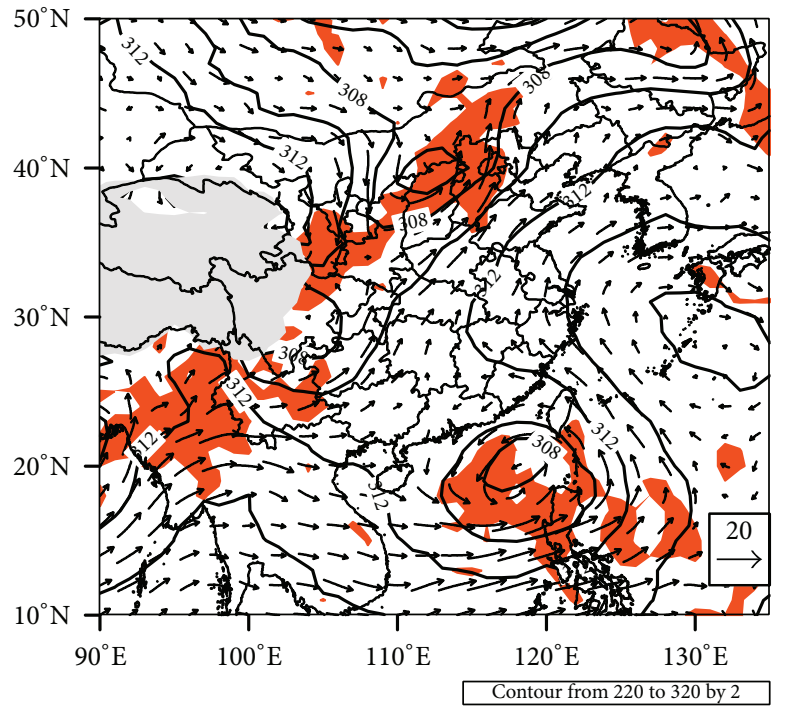

(a) $700 \mathrm{hPa}$

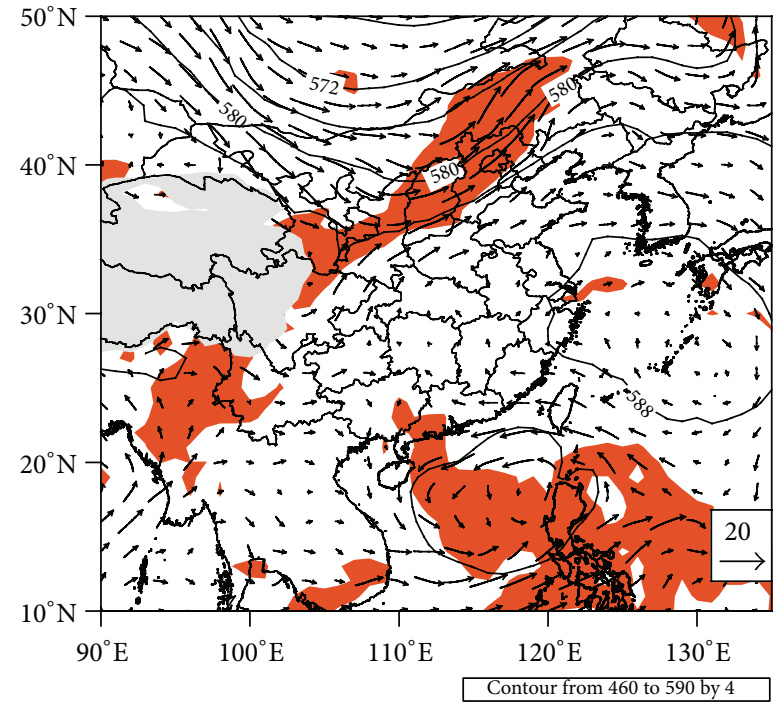

(b) $500 \mathrm{hPa}$

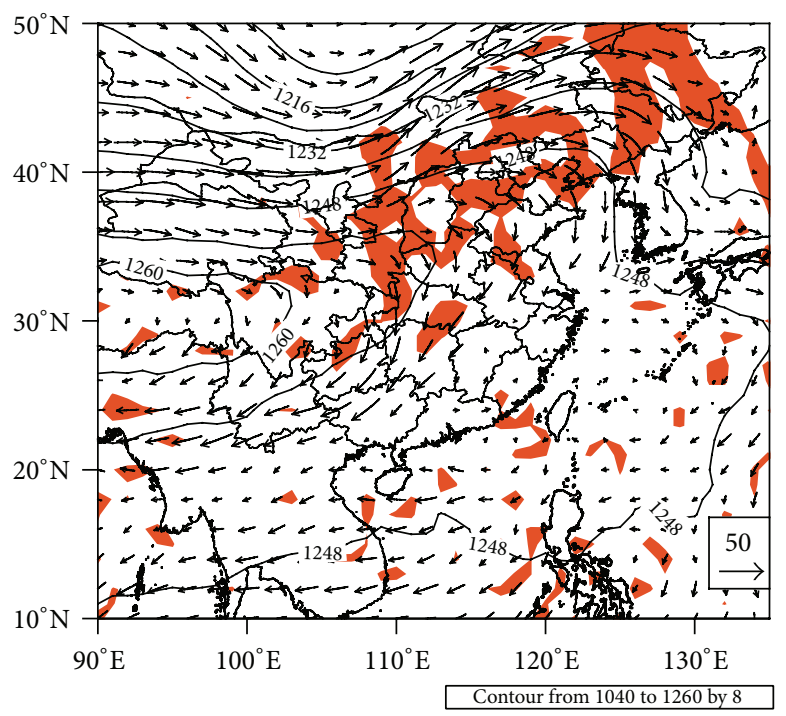

(c) $200 \mathrm{hPa}$

Figure 2: Geopotential height (solid) and wind barbs from the NCEP FNL analysis at 0600 UTC 21 July 2012 at (a) $700 \mathrm{hPa}$ and (b) $500 \mathrm{hPa}$ with the relative humidity exceeding $90 \%$ shaded, (c) $200 \mathrm{hPa}$ with the horizontal divergence less than $-5 \times 10^{-5} \mathrm{~s}^{-1}$ shaded.

of CTRL experiment can reasonably represent the extreme rainfall, which can be further utilized to analyze the roles of topography played in the event. A comparative investigation of the differences between CTRL and TOP0.25 is reasonable.

\section{Topography Effect and Echo-Training}

Figure 7 shows the mean sea level pressure and pw of experiments at 18 UTC 21 July 2012. A quasi-steady low pressure locates at east of Taihang Mountain in CTRL experiment (Figure 7(a)). The sustained uplifting exists over mountain slope with adiabatic cooling and an associated positivepressure perturbation. This produces a pressure gradient force directed upstream of the mountain barrier [32].
In the present case, it indicates that the Taihang Mountain exerted an influence on the movement of the low pressure.

Lifting along convergence line is responsible for the repeated initiation of convection $[6,33]$. Topography affected the incoming LLJ (low-level jet) from east, causing a quasisteady moisture transport and convergence line along the Taihang Mountain. This convergence line is extended along the mountain to Beijing region. At particular times and points, lifting along the convergence line is sufficient for parcels to reach their LFC, initiating deep convection [6]. A further examination of the divergence and radar reflectivity from CTRL experiment shows the convective cells clearly initiated and moved along the convergence line (Figures 10(a) and $10(\mathrm{c})$ ). Thus, linear shaped MCSs with the convective 


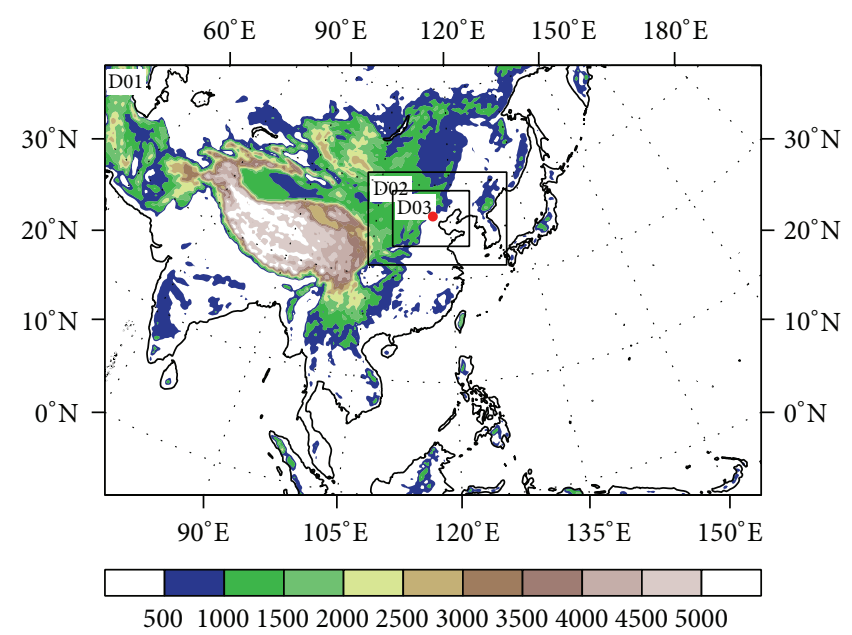

Figure 3: The model domain. The outer box is d01 $(30 \mathrm{~km})$, the inner boxes are d02 (10 km) and d03 $(3.3 \mathrm{~km})$, red dot indicate Beijing.

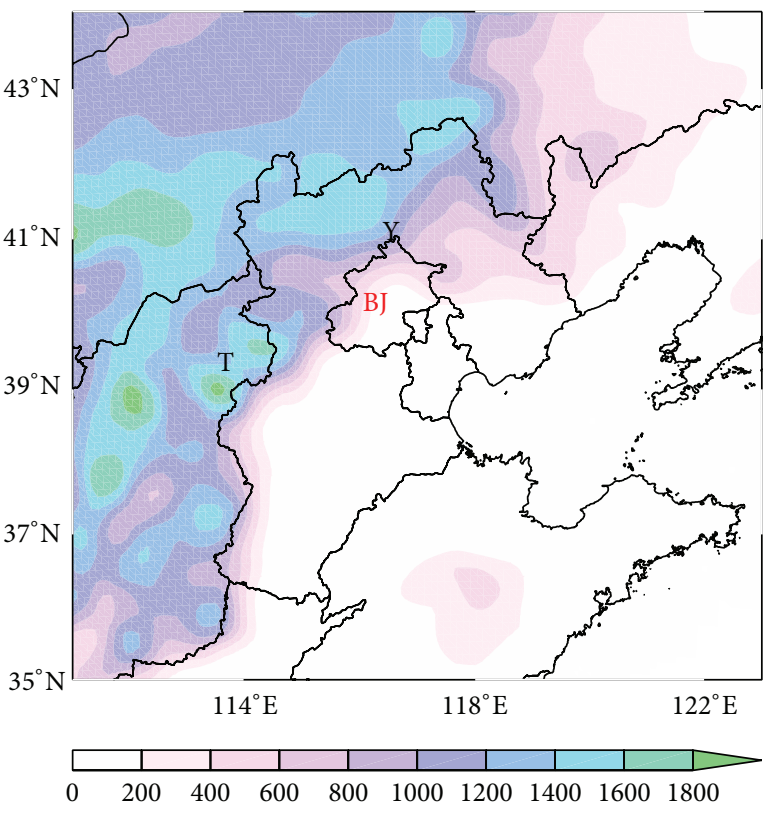

(a) CTRL

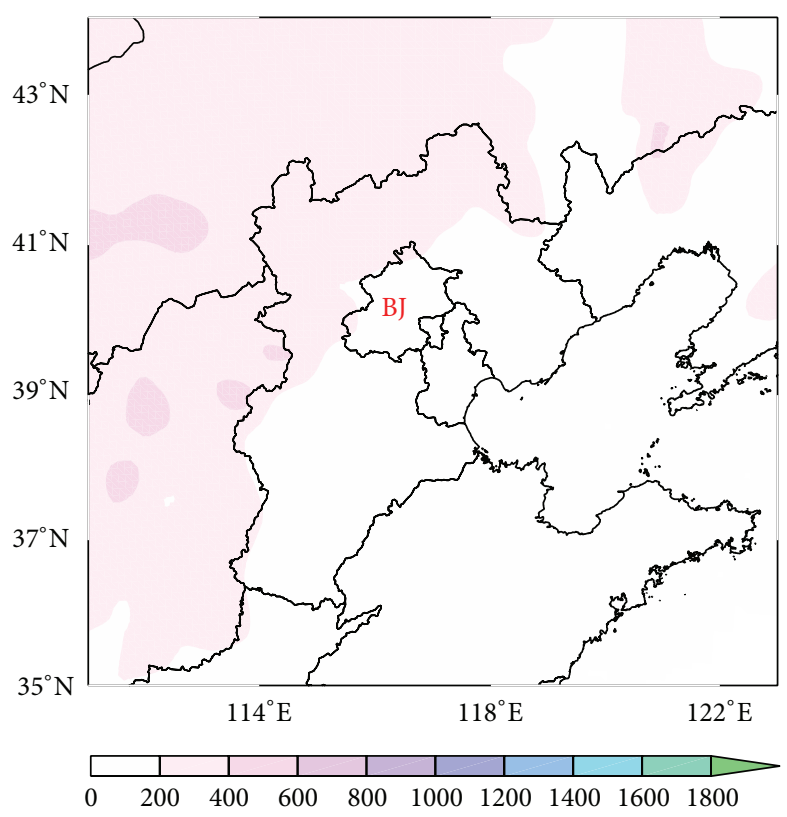

(b) TOP0.25

Figure 4: Elevation (shaded, unit: $\mathrm{m}$ ) from (a) the actual and (b) \%25 mountain topographic grids; "T" and "Y" indicate Taihang Mountain and Yanshan Mountain.

cells moved slowly to Beijing and caused this extreme rainfall. These features are similar to the "back-building/quasistationary" (BB) discussed by Schumacher and Johnson [1], Schumacher and Johnson [5].

To investigate the effect of topography, we compare the reduced topography in TOP0.25 experiment with actual topography in CTRL. With reduced topography in TOP0.25, the surface low (Figure 7(b)) moved across the mountain area. It finally located at southwest of Hebei province. As shown in Figure 8(b), the LLJ for TOP0.25 moved further west compared to CTRL. The topography plays an important role in the activity of the quasi-steady mesolow and LLJ.
As in Schumacher and Johnson [1], the presence and location of mesolow near the region of upstream convective development raise the possibility that convergence associated with the mesolow assisted in maintaining the heavy-rainproducing MCS. Such a mechanism is important for quasistationary convection $[34,35]$. MCSs which repeatedly pass over the same area are more possible to produce extreme rainfall than nonlinear ones [7]. Convective activity may also be significantly influenced by topography. The linear shaped MCSs in CTRL experiment (Figures 9(a), 9(c) and 9(e)) with more convective cells move much slowly than that scatter shaped ones in TOP0.25 experiment (Figures 9(b), 9(d) and $9(\mathrm{f})$ ), and is contributive more to heavy rainfall. 


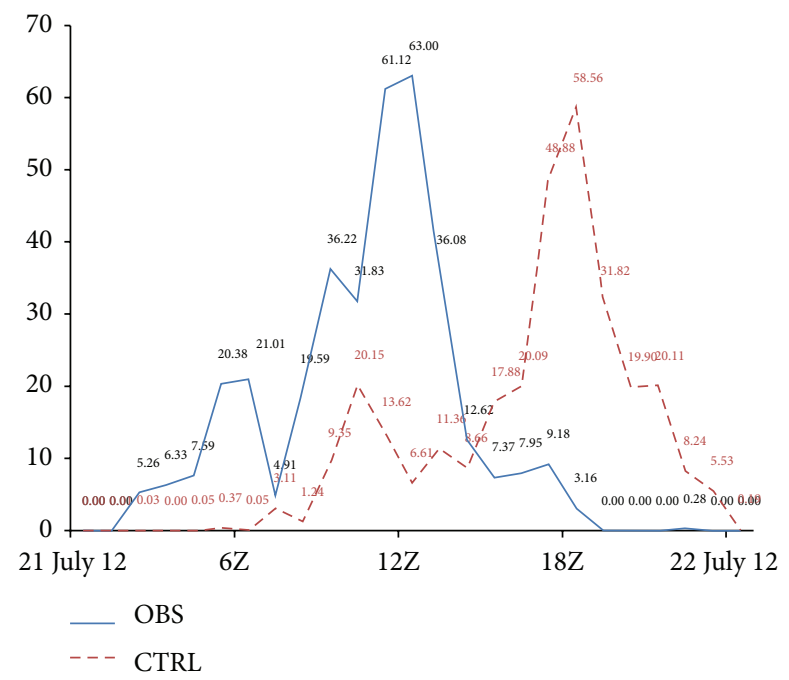

FIgure 5: Time series of observation (solid) and CTRL (dash) at Fangshan $\left(115.98^{\circ} \mathrm{E}, 39.72^{\circ} \mathrm{N}\right)$.

Figure 10 shows the vertical motion (shaded, $\mathrm{m} \mathrm{s}^{-1}$ ) and potential temperature perturbation (contours) in CTRL and TOP0.25 experiment. In CTRL experiment, several convection cells are apparent and move along the topography of the Taihang Mountain in the cross section. Taihang Mountain significantly influenced the initiation and movement of convective cells, which generated extreme rainfall over Beijing. A comparison of Figures 10(a), 10(c), 10(b), and 10(d) suggests that the reduction of topography accounted for fewer realistically organized convection cells forming upstream and passing over the foot of the mountain Taihang.

The $24 \mathrm{~h}$ accumulated rainfall of TOP 0.25 experiment and time series of $1 \mathrm{~h}$ rainfall for the two simulations at Fangshan station are shown in Figure 11(a). It can be seen clearly that the effect of topography is not only on the rainfall amount but also on its distribution. The maximum precipitation of TOP0.25 experiment shows a 30\% decrease, and the location of the peak value moves to the west of Beijing. If this kind of situation really had happened in this event, it might have saved lots of people's lives and properties in this region.

In order to investigate the rainfall differences of the two experiments, time series of $1 \mathrm{~h}$ rainfall at Fangshan station of both TOP0.25 and CTRL experiments are shown in Figure 11. Due to the significant reduction of rainfall intensity in TOP0.25 experiment, the peak rainfall of it only reaches $31.03 \mathrm{~mm}$ in Fangshan area, which equates to only about 50\% of the difference.

In total, these are where the differences between CTRL and TOP0.25 experiments-and the importance of the topography-become especially clear. Topography affected the incoming LLJ (low-level jet) from east, causing extra moisture and stationary mesolow east of the Taihang Mountain, which assisted in maintaining the convergence line. This convergence line was extended along the mountain to Beijing region. At particular times and points, lifting along the convergence line was sufficient for parcels to reach their LFC, initiating deep convection. As a result, the repeated initiation and movement of the line shape convective cells at the leading convergence line region along Taihang Mountain produced the long-time extreme rainfall event over Beijing. The effect of topography not only reduced rainfall significantly, but also altered its distribution.

\section{Summary and Conclusions}

The extreme rainfall occurring during 21 July 2012 is the heaviest rainfall event ever hitting Beijing since 1961. The WRF model is utilized in this study to simulate the development of this recorded torrential rainfall. Control and sensitivity experiments are carried out with topography in initial conditions of sensitivity experiment artificially modified to investigate its effects on the extreme rainfall.

From the synoptic point of view, North China was dominated by a favorable large-scale environment on 21 July. It showed a southwesterly monsoonal flow with high moisture over the eastern plain region of China. Typhoon Vicente located at South China Sea altered moisture from southwesterly monsoonal flow to Beijing region along with the southeast flow east of $\mathrm{SH}$. The upper-level trough blocked by $\mathrm{SH}$ also significantly influenced the rainfall event. In short, the large-scale synoptic environment provided very moist conditions for the rainfall and MCS.

The WRF model can reasonably reproduce the spatial and intensity patterns of the rainfall. In particular, the model simulated extreme rainfall amount is over $320 \mathrm{~mm}$ and shows two significant rainfall centers in Beijing, which is in good agreement with the observations. It is notable that the evolution of rainfall shows two major peaks and nearly the same intensity as the observations only albeit with a $4-6 \mathrm{~h}$ delay.

In our CTRL experiment, the activity of the MCS is well reproduced. Similar to observations, the simulated MCS develops into a quasi-linear MCS. LLJ is blocked which 


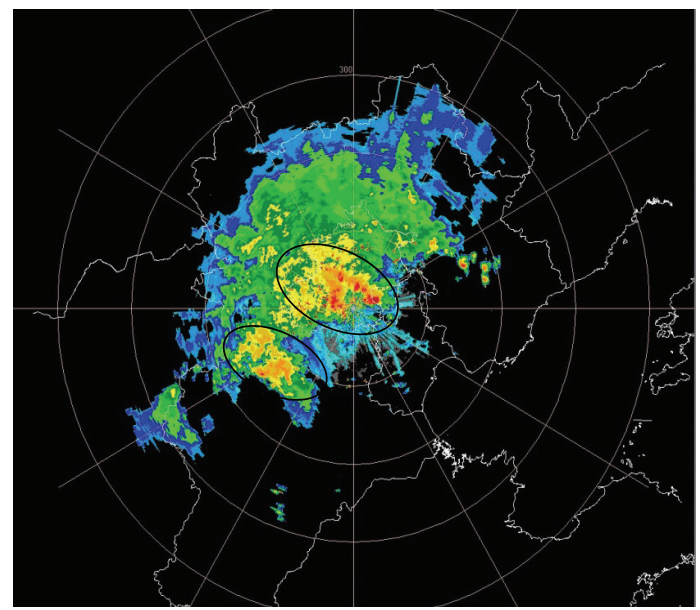

(a) 06 UTC 21

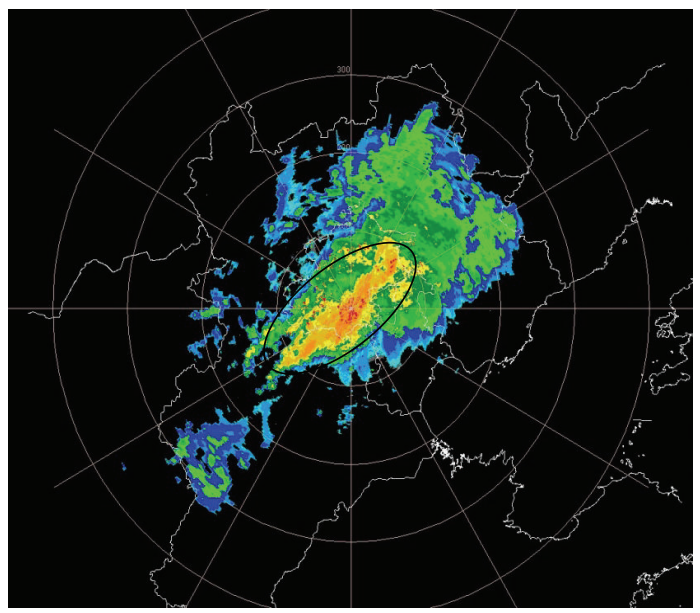

\begin{tabular}{ll|llllllllllllll}
$(\mathrm{dBZ})$ & 0 & 5 & 10 & 15 & 20 & 25 & 30 & 35 & 40 & 45 & 50 & 55 & 60 & 65 & $70>75$
\end{tabular}

(c) 12 UTC 21

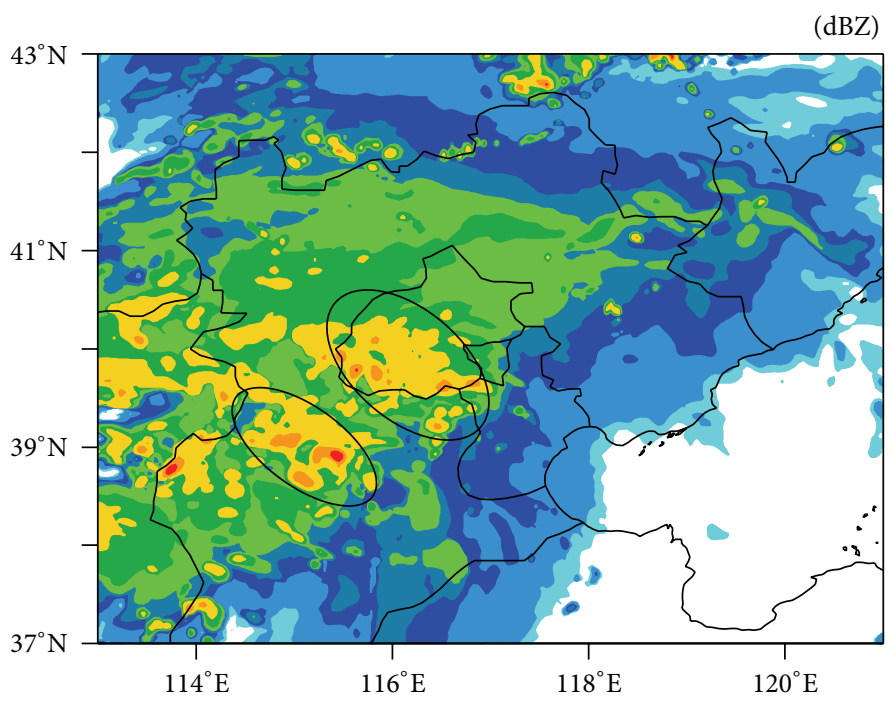

(b) 10 UTC 21

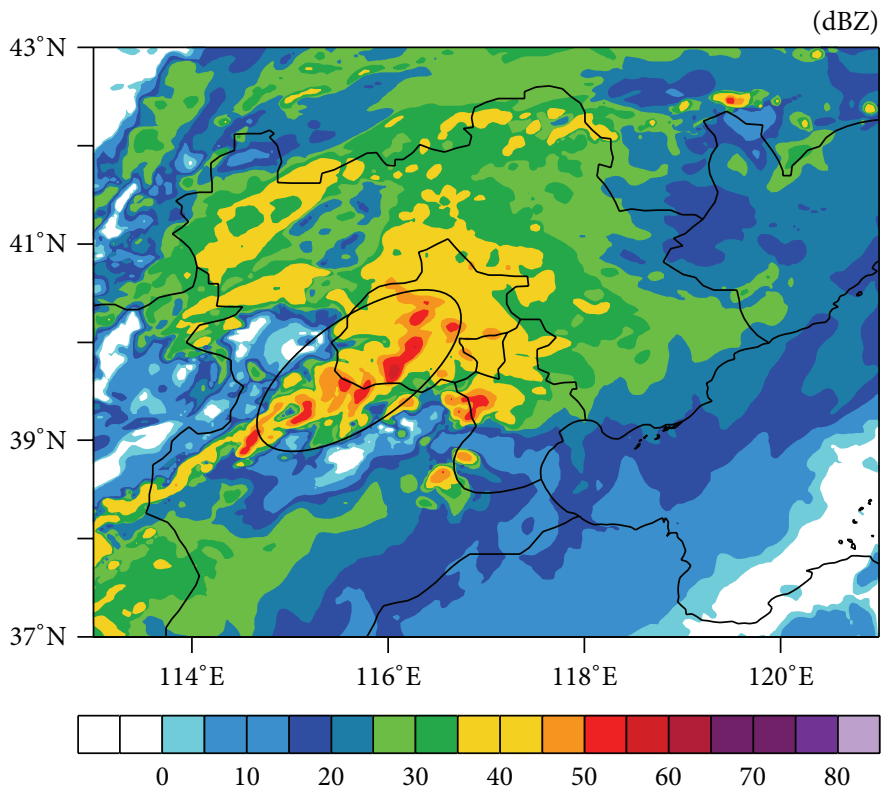

(d) 18 UTC 21

FIGURE 6: Radar reflectivity (DBZ) from Beijing site at (a) 0600 and (c) 1200 UTC 21 July and simulated reflectivity at (b) 1000 and (d) 1800 UTC 21 July.

causes a quasi-steady moisture transport along the Taihang Mountains. Under the influence of topography, the quasisteady mesolow located at the south of Beijing. As a result, the convergence line extended from the mountain area to Beijing region. In such case, the convective cells repeatedly moved along the Taihang Mountains in rapid successions and further induced the extreme rainfall.

Detailed analyses of the sensitivity experiment with 25\% topography and that of CTRL experiment show that LLJ and the low surface move across the reduced topography to west of Beijing. The linear shaped MCS in CTRL experiment is replaced by a scatter shaped MCS in TOP0.25 experiment.
The effect of topography reduced rainfall amount and altered its distribution significantly. The maximum precipitation in TOP0.25 experiment shows a 30\% decrease, and the peak location is positioned west of Beijing. All these features are consistent with the idea of Schumacher and Johnson $[1,5]$, and the organization and motion characteristics of MCSs are crucial in determining whether they will produce relatively small rainfall amounts over a large area or extremely large rainfall amounts over a local area which can lead to a flash flood threat. In this heavy rainfall case, some environment conditions such as the topography near Beijing, the development of the surface mesolow, and the very moist 


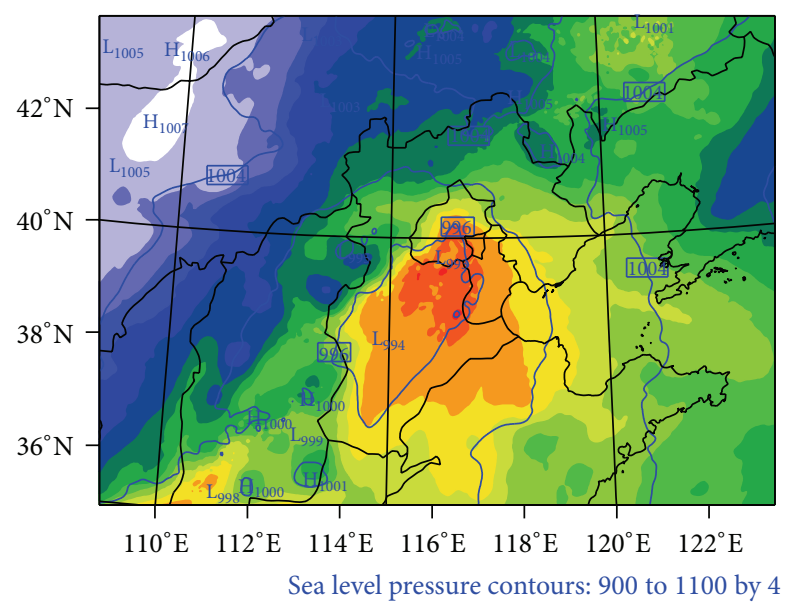

$\begin{array}{llllllllllllll}15 & 20 & 25 & 30 & 35 & 40 & 45 & 50 & 55 & 60 & 65 & 70 & 75 & 80\end{array}$

Precipitable water

(a) CTRL

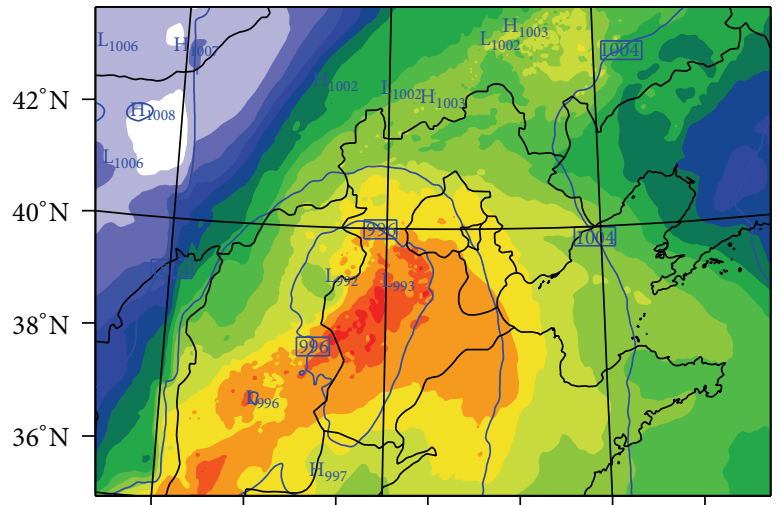

$110^{\circ} \mathrm{E} \quad 112^{\circ} \mathrm{E} \quad 114^{\circ} \mathrm{E} \quad 116^{\circ} \mathrm{E} \quad 118^{\circ} \mathrm{E} \quad 120^{\circ} \mathrm{E} \quad 122^{\circ} \mathrm{E}$

Sea level pressure contours: 900 to 1100 by 4

$\begin{array}{llllllllllllll}15 & 20 & 25 & 30 & 35 & 40 & 45 & 50 & 55 & 60 & 65 & 70 & 75 & 80\end{array}$ Precipitable water

(b) TOP0.25

FIGURE 7: Modeled mean sea level pressure (contour, hPa) superposed with precipitable water (pw) (shaded, mm) for (a) CTRL, (b) TOP0.25 at 18 UTC 21 July 2012.

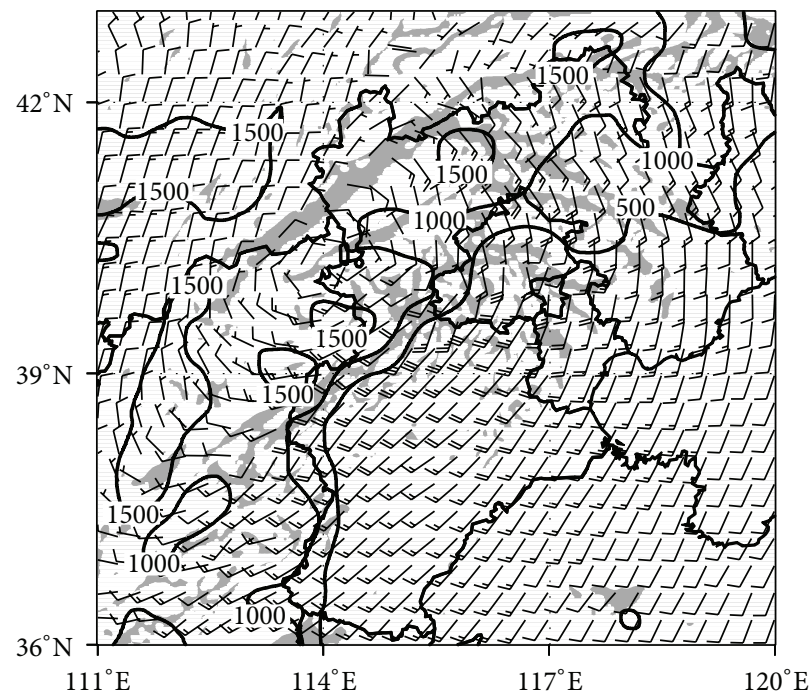

(a) CTRL

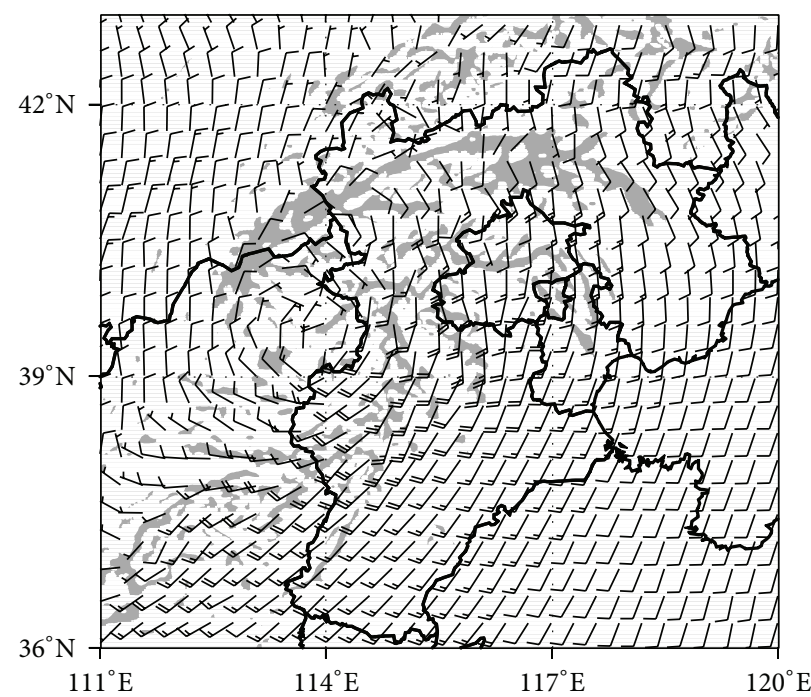

(b) TOP0.25

FIGURE 8: Simulated divergence (shaded, greater than $1 \times 10^{-4} \mathrm{~s}^{-1}$ ) with terrain height (contour) at 1800 UTC 21 July 2012 from (a) CTRL and (b) TOP0.25.

environment existing on 21 July 2012 might make the Beijing extreme rainfall happen.

Future work is aimed at studying several other extreme rainfalls produced by linear MCSs associated with topography to summarize their common characteristics. Furthermore, we hope to investigate the roles of topography played in organizing convection, which was developed in a favorable moist environment. The goal of this research is to improve the understanding and the ability to predict extreme-rainproducing MCS in the complex terrain area.

\section{Conflict of Interests}

The authors declare that there is no conflict of interests regarding the publication of this paper.

\section{Acknowledgments}

This study is supported by the National Natural Science Foundation of China (Grant no. 91437106) and the State Key Program of National Natural Science Foundation of China 


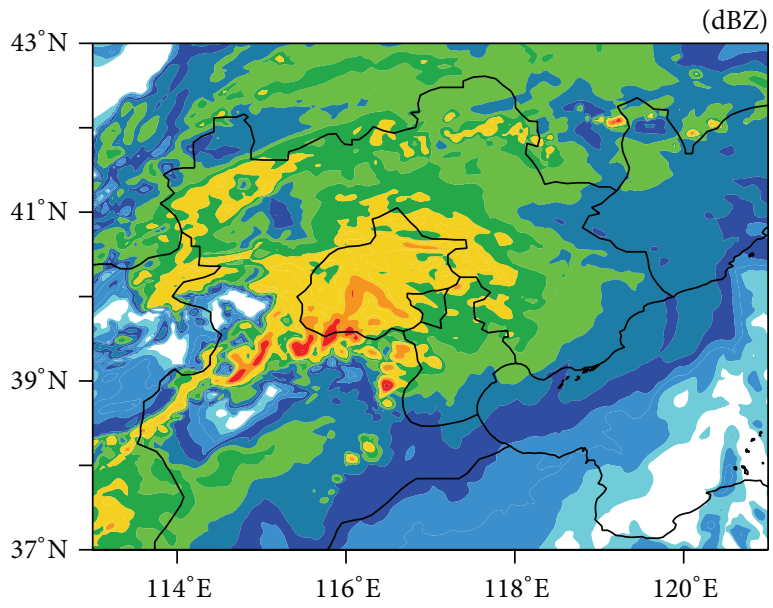

(a) CTRL 17 UTC 21

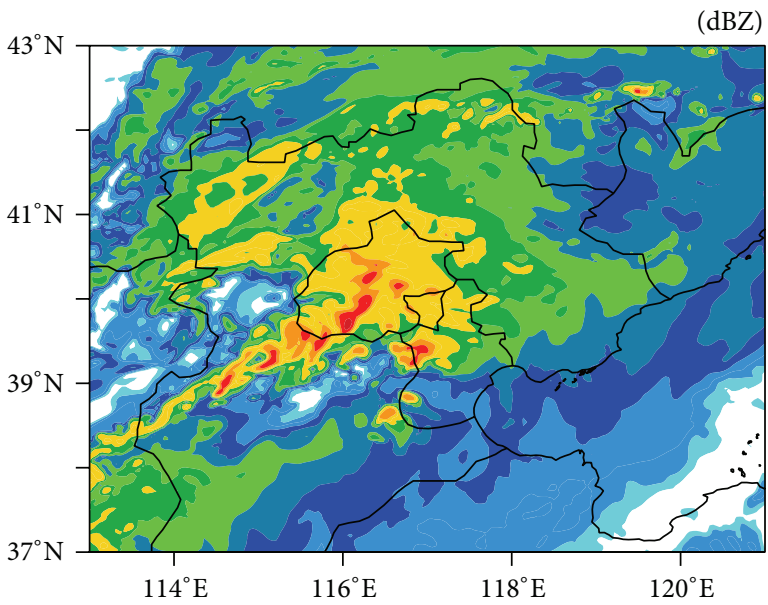

(c) CTRL 18 UTC 21

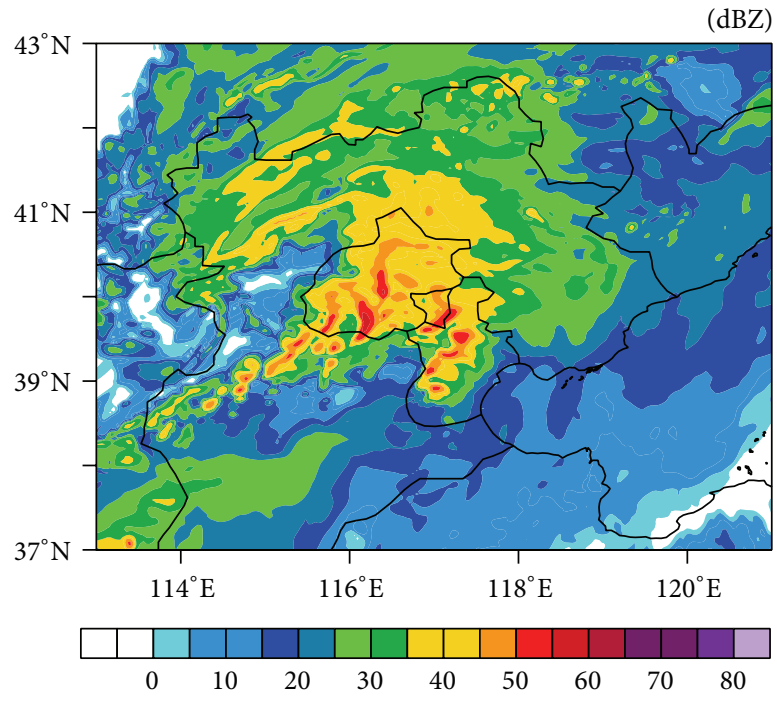

(e) CTRL 19 UTC 21

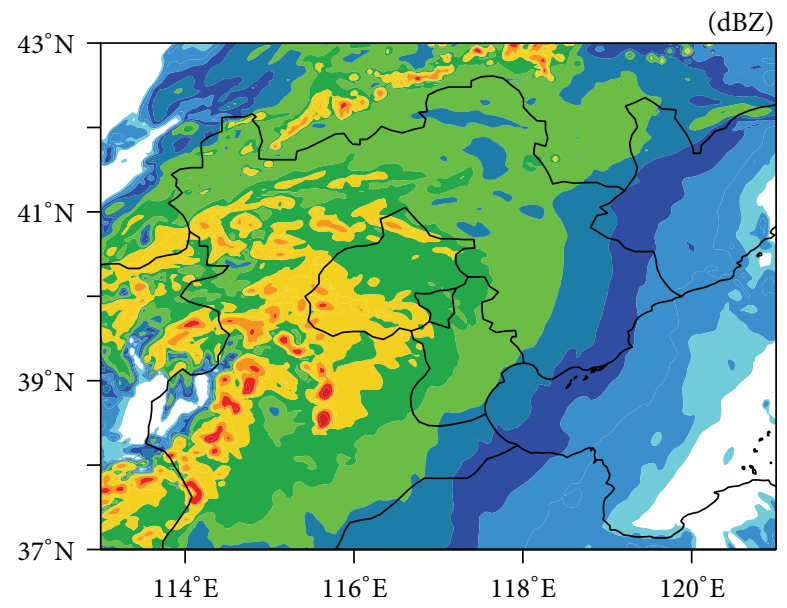

(b) TOP0.25 17 UTC 21

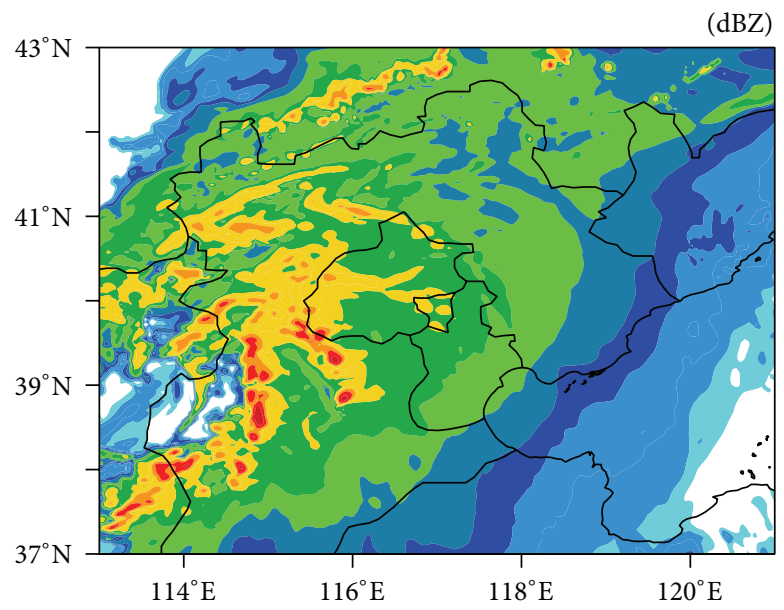

(d) TOP0.25 18 UTC 21

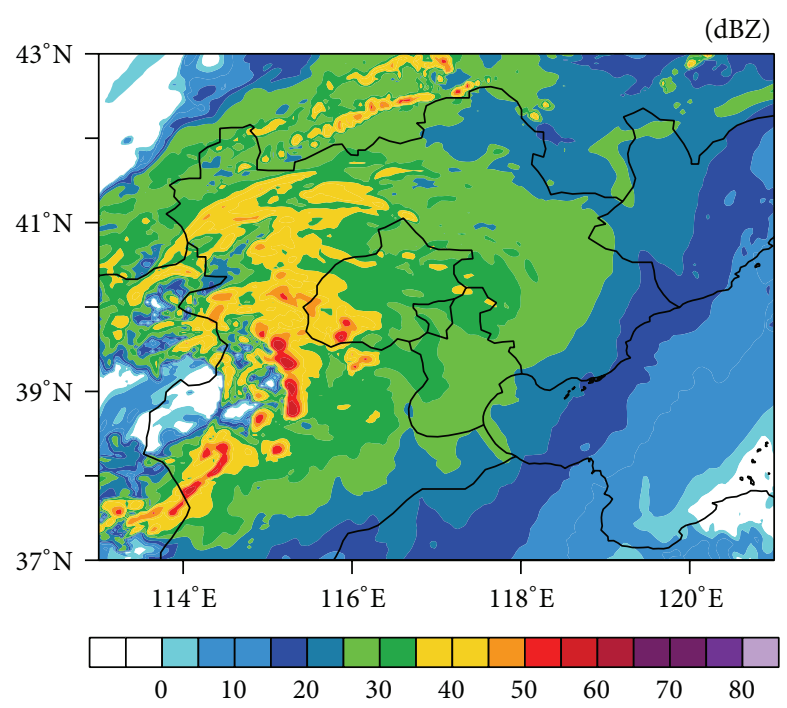

(f) TOP0.25 19 UTC 21

FIGURE 9: Radar reflectivity (shadings, units: dbz) over a subdomain of D3 for CTRL experiment at (a) 1700 UTC, (c) 1800 UTC, (e) 1900 UTC JUL2012. (b), (d), and (f) as in (a), (c) and (e), respectively, but for the TOP0.25 experiment. 


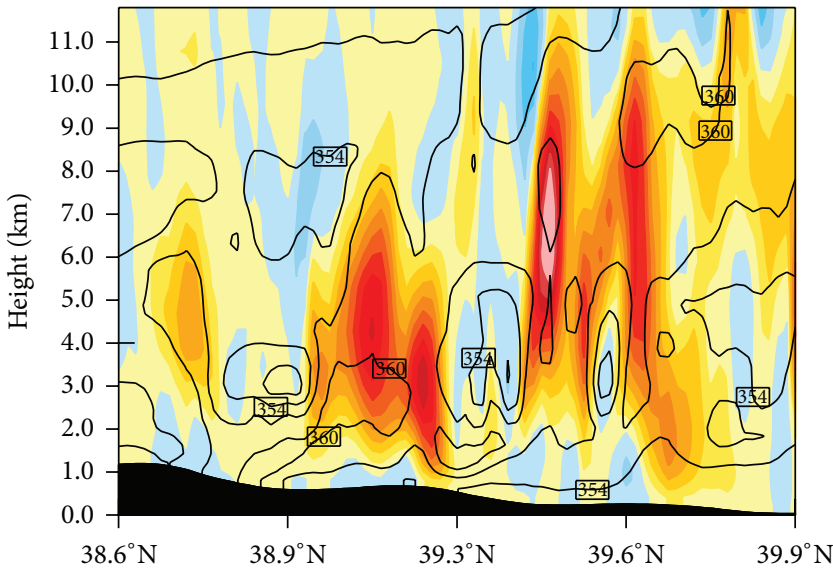

Equivalent potential temperature contours: 345 to 366 by 3

(a) 17 UTC 21

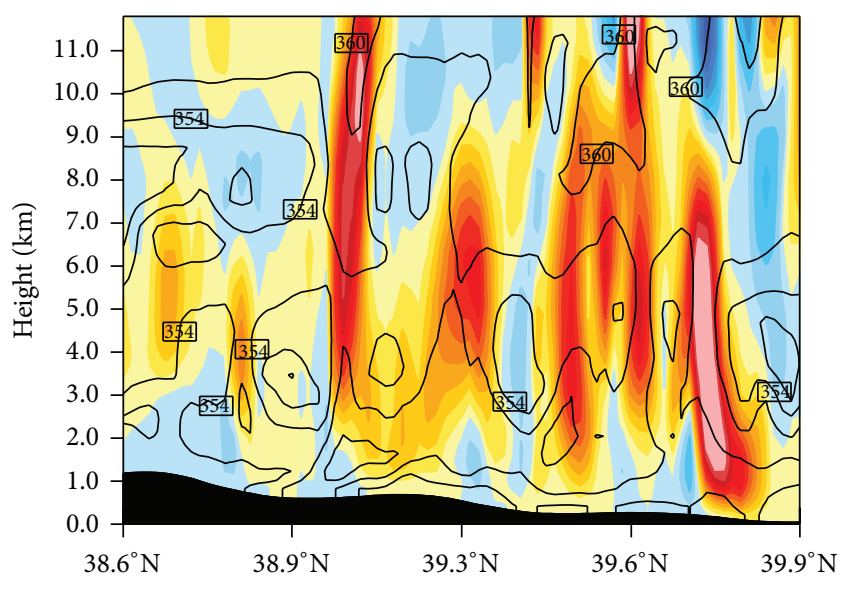

Equivalent potential temperature contours: 345 to 366 by 3

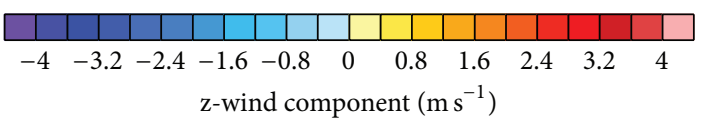

(c) 18 UTC 21

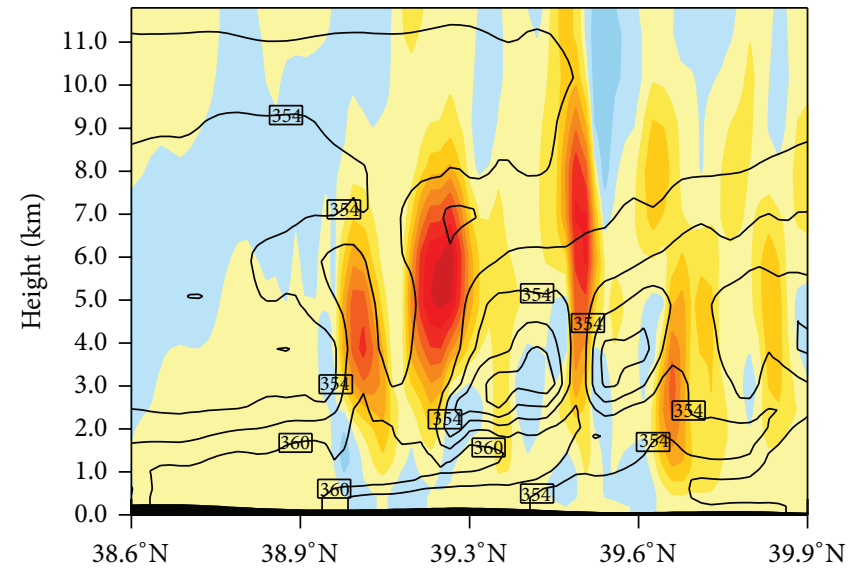

Equivalent potential temperature contours: 345 to 366 by 3

(b) 17 UTC 21

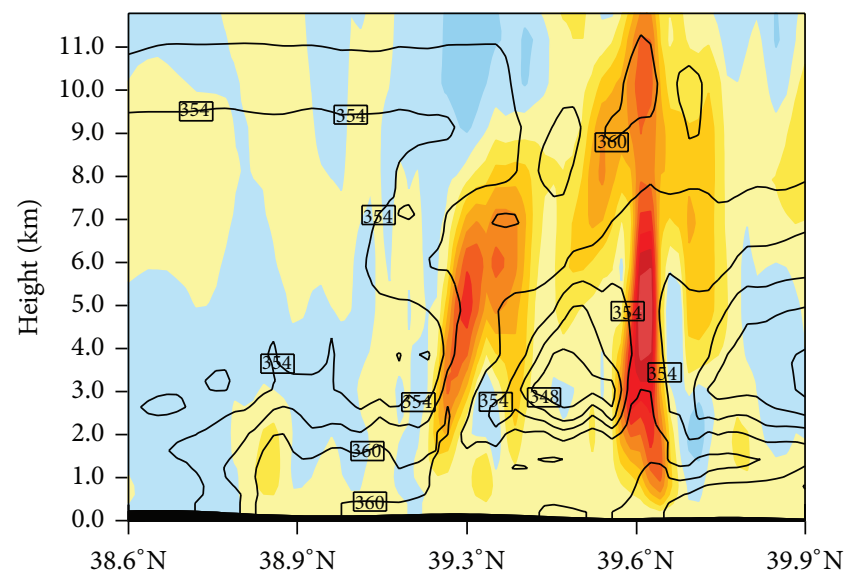

Equivalent potential temperature contours: 345 to 366 by 3

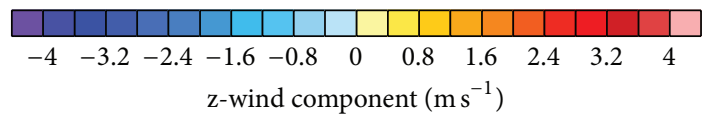

(d) 18 UTC 21

FIGURE 10: Cross section of vertical motion (shaded, $\mathrm{m} \mathrm{s}^{-1}$ ) and equivalent potential temperature (contours) for CTRL experiment at (a) 1700 UTC, (c) 1800 UTC. (b), (d) as in (a) and (c), respectively, but for the TOP0.25 experiment.

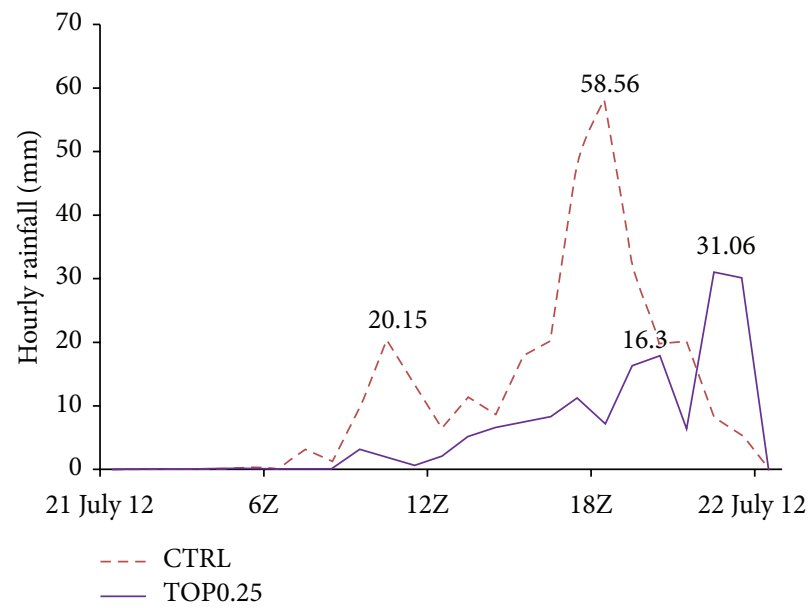

FIgURE 11: Time series of $1 \mathrm{~h}$ rainfall from CTRL (dash) and TOP0.25 (solid) at Fangshan $\left(115.98^{\circ} \mathrm{E}, 39.72^{\circ} \mathrm{N}\right)$. 
(Grant no. 41130960). The authors would like to thank all the reviewers and editors for their professional advices to improve the paper.

\section{References}

[1] R. S. Schumacher and R. H. Johnson, "Mesoscale processes contributing to extreme rainfall in a midlatitude warm-season flash flood," Monthly Weather Review, vol.136, no. 10, pp. 3964-3986, 2008.

[2] M. Zhang and D.-L. Zhang, "Subkilometer simulation of a torrential-rain-producing mesoscale convective system in East China. Part I: model verification and convective organization," Monthly Weather Review, vol. 140, no. 1, pp. 184-201, 2012.

[3] L. Zhang and Z. Pu, "Four-dimensional assimilation of multitime wind profiles over a single station and numerical simulation of a mesoscale convective system observed during IHOP_2002," Monthly Weather Review, vol. 139, no. 11, pp. 33693388, 2011.

[4] J. M. Fritsch and R. E. Carbone, "Improving quantitative precipitation forecasts in the warm season: a USWRP research and development strategy," Bulletin of the American Meteorological Society, vol. 85, no. 7, pp. 955-965, 2004.

[5] R. S. Schumacher and R. H. Johnson, "Organization and environmental properties of extreme-rain-producing mesoscale convective systems," Monthly Weather Review, vol. 133, no. 4, pp. 961-976, 2005.

[6] R. A. Warren, D. J. Kirshbaum, R. S. Plant, and H. W. Lean, "A 'Boscastle-type' quasi-stationary convective system over the UK Southwest Peninsula," Quarterly Journal of the Royal Meteorological Society, vol. 140, no. 678, pp. 240-257, 2014.

[7] R. A. Houze Jr., B. F. Smull, and P. Dodge, "Mesoscale organization of springtime rainstorms in Oklahoma," Monthly Weather Review, vol. 118, no. 3, pp. 613-654, 1990.

[8] M. D. Parker and R. H. Johnson, "Organizational modes of midlatitude mesoscale convective systems," Monthly Weather Review, vol. 128, no. 10, pp. 3413-3436, 2000.

[9] M. D. Parker and R. H. Johnson, "Structures and dynamics of quasi-2D mesoscale convective systems," Journal of the Atmospheric Sciences, vol. 61, no. 5, pp. 545-567, 2004.

[10] Y. Zhao, "Numerical investigation of a localized extremely heavy rainfall event in complex topographic area during midsummer," Atmospheric Research, vol. 113, pp. 22-39, 2012.

[11] Y. Lemaitre and P. Brovelli, "Role of a low level jet in triggering and organizing moist convection in a baroclinic atmosphere. A case study: 18 May 1984," Journal of the Atmospheric Sciences, vol. 47, no. 1, pp. 82-100, 1990.

[12] R. Rotunno and R. A. Houze, "Lessons on orographic precipitation from the Mesoscale Alpine Programme," Quarterly Journal of the Royal Meteorological Society, vol. 133, no. 625, pp. 811-830, 2007.

[13] Y.-L. Lin, S. Chiao, T.-A. Wang, M. L. Kaplan, and R. P. Weglarz, "Some common ingredients for heavy orographic rainfall," Weather and Forecasting, vol. 16, no. 6, pp. 633-660, 2001.

[14] C.-C. Wu, K. K. W. Cheung, J.-H. Chen, and C.-C. Chang, "The impact of tropical storm paul (1999) on the motion and rainfall associated with tropical storm rachel (1999) near Taiwan," Monthly Weather Review, vol. 138, no. 5, pp. 1635-1650, 2010.

[15] C. A. Doswell III, H. E. Brooks, and R. A. Maddox, "Flash flood forecasting: an ingredients-based methodology," Weather and Forecasting, vol. 11, no. 4, pp. 560-581, 1996.
[16] W. Jiali, Z. Renhe, and W. Yingchun, "Characteristics of precipitation in beijing and the precipitation representativeness of Beijing weather observatory," Journal of Applied Meteorological Science, vol. 23, no. 3, pp. 265-273, 2012.

[17] X. Zhuang and W. Guitian, "The changes of temperature and precipitation in Beijing during last 100 years," Chinese Journal of Atmospheric Sciences, vol. 18, no. 6, pp. 683-690, 1994 (Chinese).

[18] D.-L. Zhang, Y. Lin, P. Zhao et al., "The Beijing extreme rainfall of 21 July 2012: 'right results' but for wrong reasons," Geophysical Research Letters, vol. 40, no. 7, pp. 1426-1431, 2013.

[19] R. H. Grumm, Beijing Flood of 21 July 2012, 2012.

[20] Y. Wang and H. Fudeyasu, "The role of Typhoon Songda (2004) in producing distantly located heavy rainfall in Japan," Monthly Weather Review, vol. 137, no. 11, pp. 3699-3716, 2009.

[21] X. Yu, "Investigation of Beijing extreme flooding event on 21 July 2012," Meteorological Monthly, vol. 38, no. 11, pp. 1313-1328, 2012.

[22] W. C. Skamarock, J. B. Klemp, J. Dudhia et al., "A description of the advanced research WRF version 3," NCAR Technical Note NCAR/TN-475+STR, 2008.

[23] S.-Y. Hong and J.-O. J. Lim, "The WRF single-moment 6class microphysics scheme (WSM6)," Journal of the Korean Meteorological Society, vol. 42, no. 2, pp. 129-151, 2006.

[24] S.-Y. Hong and H.-L. Pan, "Nonlocal boundary layer vertical diffusion in a medium-range forecast model," Monthly Weather Review, vol. 124, no. 10, pp. 2322-2339, 1996.

[25] J. S. Kain, "The Kain-Fritsch convective parameterization: an update," Journal of Applied Meteorology, vol. 43, no. 1, pp. 170181, 2004.

[26] J. S. Kain, "Convective parameterization for mesoscale models: the Kain-Fritsch scheme," in The Representation of Cumulus Convection in Numerical Models of the Atmosphere, vol. 46 of Meteorological Monographs, pp. 165-170, 1993.

[27] F. Chen and J. Dudhia, "Coupling an advanced land surfacehydrology model with the Penn-State-NCAR MM5 modeling system. Part II: preliminary model validation," Monthly Weather Review, vol. 129, no. 4, pp. 587-604, 2001.

[28] F. Chen and J. Dudhia, "Coupling and advanced land surfacehydrology model with the Penn State-NCAR MM5 modeling system. Part I: model implementation and sensitivity," Monthly Weather Review, vol. 129, no. 4, pp. 569-585, 2001.

[29] E. J. Mlawer, S. J. Taubman, P. D. Brown, M. J. Iacono, and S. A. Clough, "Radiative transfer for inhomogeneous atmospheres: RRTM, a validated correlated-k model for the longwave," Journal of Geophysical Research D: Atmospheres, vol. 102, no. 14, pp. 16663-16682, 1997.

[30] J. Dudhia, "Numerical study of convection observed during the winter monsoon experiment using a mesoscale twodimensional model," Journal of the Atmospheric Sciences, vol. 46, no. 20, pp. 3077-3107, 1989.

[31] S.-Y. Hong and J.-W. Lee, "Assessment of the WRF model in reproducing a flash-flood heavy rainfall event over Korea," Atmospheric Research, vol. 93, no. 4, pp. 818-831, 2009.

[32] T. K. Flesch and G. W. Reuter, "WRF model simulation of two Alberta flooding events and the impact of topography," Journal of Hydrometeorology, vol. 13, no. 2, pp. 695-708, 2012.

[33] G. Monk, “Topographically related convection over the British Isles," in Satellite and Radar Imagery Interpretation, pp. 305-324, Meteorological Office College, Shinfield, UK, 1987. 
[34] T. Kato and H. Goda, "Formation and maintenance processes of a stationary band-shaped heavy rainfall observed in Niigata on 4 August 1998," Journal of the Meteorological Society of Japan, vol. 79, no. 4, pp. 899-924, 2001.

[35] T. Kato, "Structure of the band-shaped precipitation system inducing the heavy rainfall observed over northern Kyushu, Japan on 29 June 1999," Journal of the Meteorological Society of Japan, vol. 84, no. 1, pp. 129-153, 2006. 

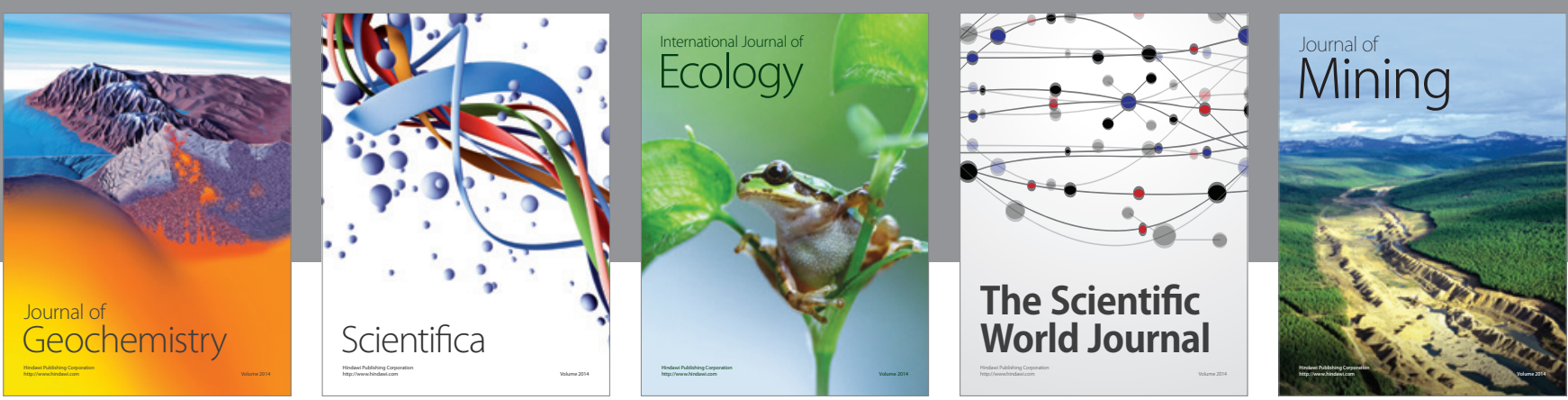

The Scientific World Journal
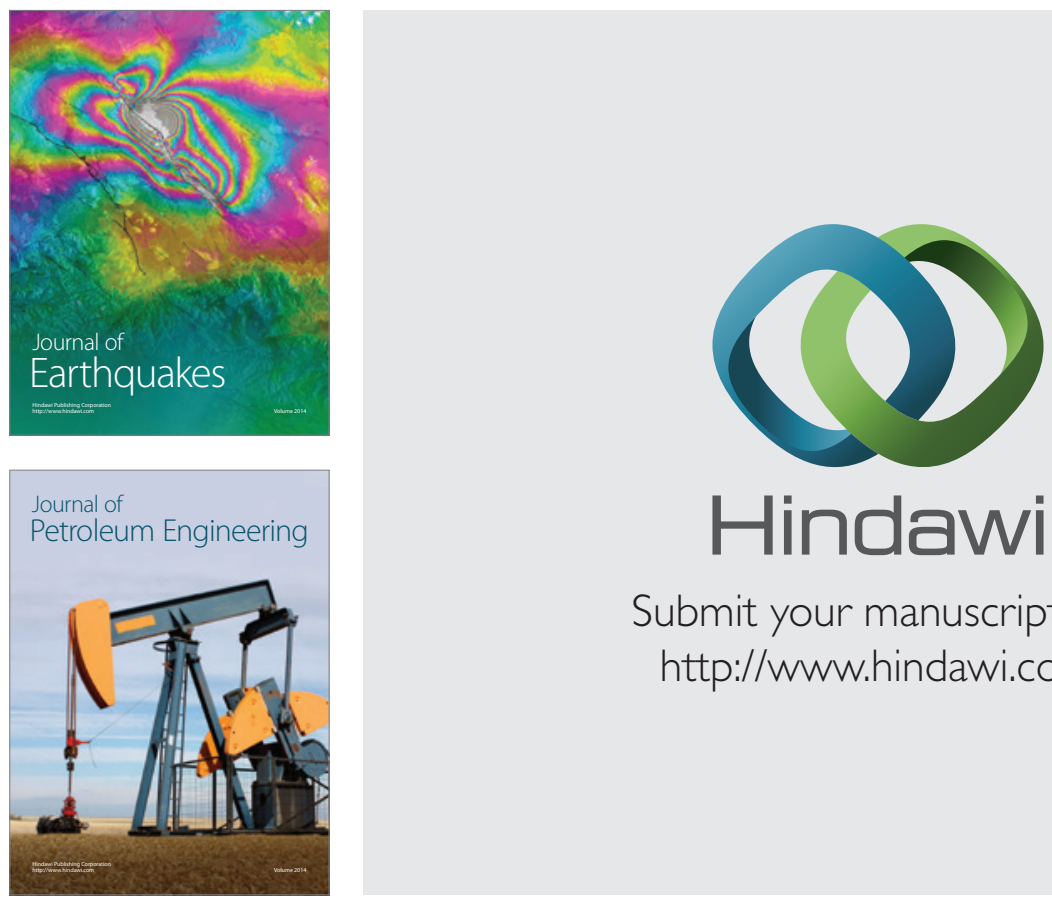

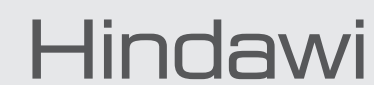

Submit your manuscripts at

http://www.hindawi.com
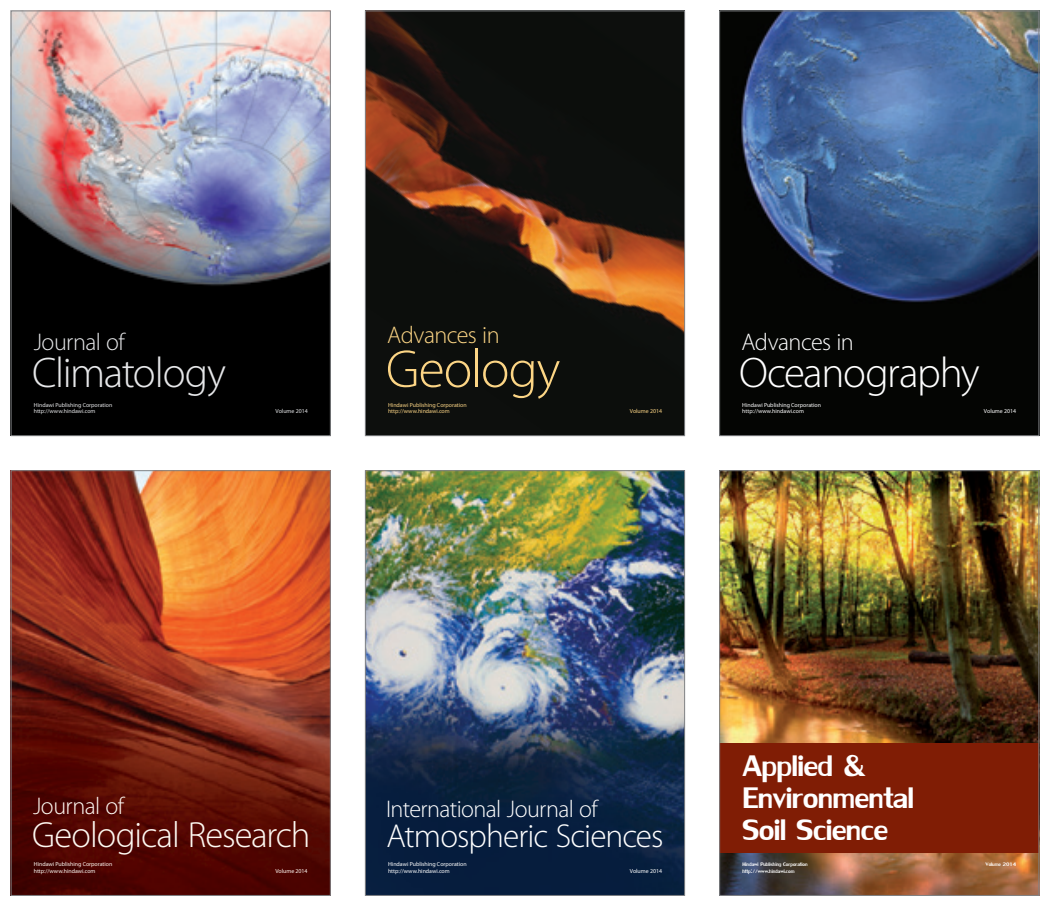
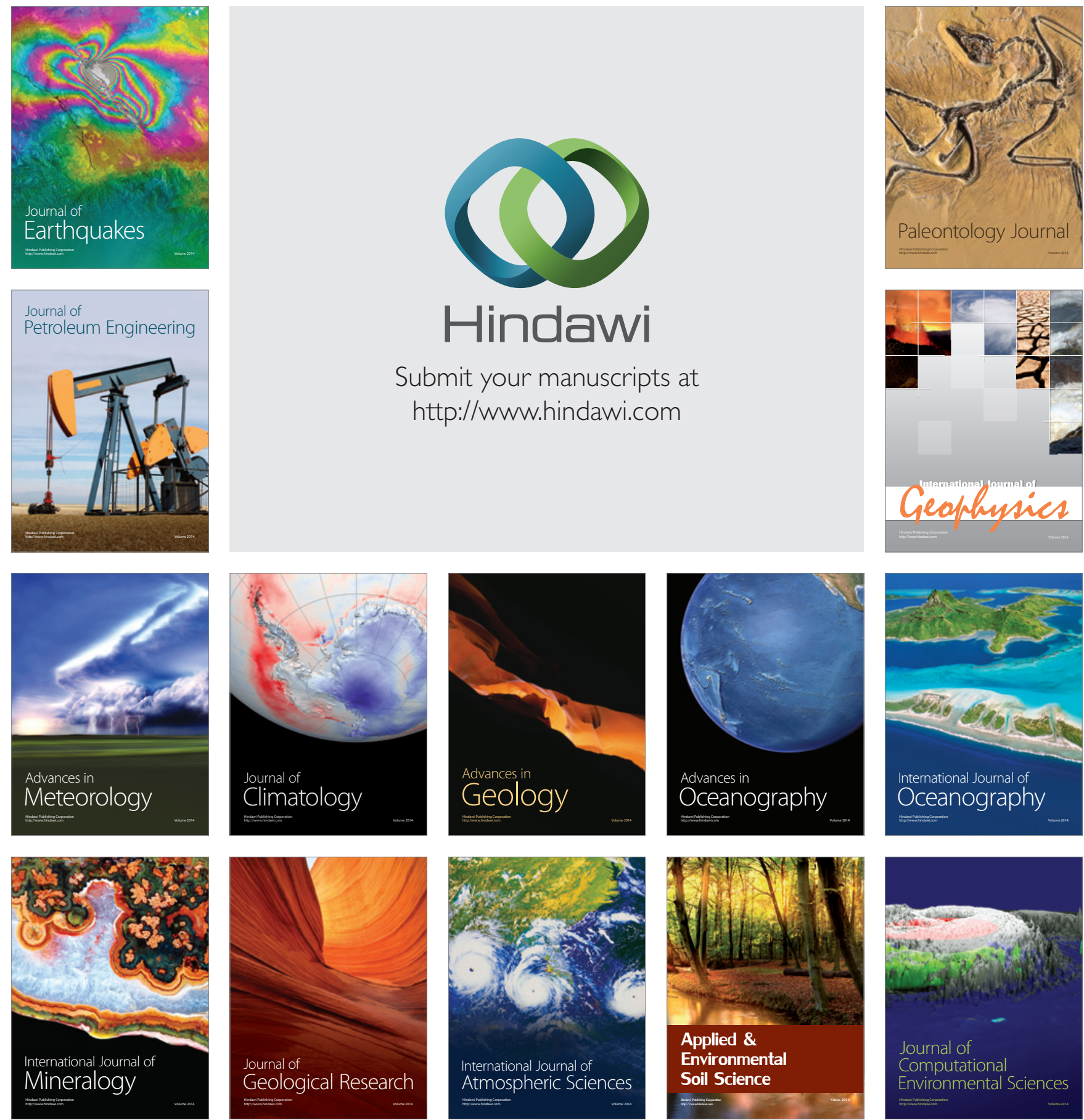